\title{
PENERAPAN APLIKASI PELAYANAN DESA BERBASIS MOBILE DENGAN KONSEP SMART VILLAGE DI DESA PEGANTENAN, KECAMATAN PEGANTENAN, KABUPATEN PAMEKASAN
}

\author{
Yanuar Risah Prayogi ${ }^{1}$, Fadilah Fahrul Hardiansyah²), Nana Ramadijanti²), Ahmad Syauqi Ahsan ${ }^{3)}$, \\ Urfiyatul Erifani ${ }^{1)}$ \\ 1)Program Studi D3Teknik Informatika, Departemen Teknik Informatika dan Komputer, Politeknik Elektronika Negeri Surabaya, \\ Surabaya, Jawa Timur, Indonesia \\ 2)Program Studi D4 Teknik Informatika, Departemen Teknik Informatika dan Komputer, Politeknik Elektronika Negeri Surabaya, \\ Surabaya, Jawa Timur, Indonesia \\ ${ }^{3)}$ Program Studi D3 Pendidikan Jarak Jauh Teknik Informatika, Departemen Teknik Informatika dan Komputer, Politeknik \\ Elektronika Negeri Surabaya, Surabaya, Jawa Timur, Indonesia \\ Corresponding author : Yanuar Risah Prayogi \\ E-mail : yanuar@pens.ac.id
}

\section{Diterima 10 November 2020, Direvisi 16 November 2020, Disetujui 16 November 2020}

\begin{abstract}
ABSTRAK
Di Desa Pegantenan hingga saat ini belum ada suatu sistem yang mampu menjembatani antara pemerintah dan masyarakat Desa Pegantenan yang memanfaatkan teknologi informasi. Pelayanan pemerintah desa masih menerapkan sistem konvensional, yang mengharuskan warga datang ke kantor desa dan membutuhkan waktu yang cukup lama. Masyarakat juga kesulitan dalam menerima informasi dan menyampaikan laporan terkait keadan desa. Pada pengabdian masyarakat ini dikembangkan sebuah aplikasi pelayanan desa berbasis mobile sehingga dapat diakses oleh seluruh masyarakat Desa Pegantenan dalam rangka mewujudkan program Smart Village dan upaya menuju Penyelenggaraan Pemerintah Desa yang transparan dan berkemajuan. Metode pelaksanaan kegiatan terdiri dari tahap pengumpulan data seperti bisnis proses dan formulir yang digunakan warga ketika mengurus surat. Tahap berikutnya pembuatan aplikasi berbasis mobile dan sosialisasi aplikasi di Desa Pegantenan sekaligus sharing session tentang pengalaman selama memakai aplikasi. Hasil dari pengabdian ini adalah berupa sistem aplikasi pelayanan Desa Pegantenan yang berbasis mobile. Selain aplikasi mobile juga ada aplikasi web yang digunakan sebagai administrator. Aplikasi mobile ditujukan untuk warga sedangkan aplikasi web ditujukan untuk admin yaitu perangkat desa. Sistem aplikasi yang barbasis mobile dan web memungkinkan warga dapat mengakses sistem dimana saja dan kapan saja sehingga meningkatkan kualitas layanan Pemerintah Desa kepada warga atau masyarakat.
\end{abstract}

Kata kunci: aplikasi pelayanan desa; aplikasi mobile; smart village; desa pegantenan.

\begin{abstract}
Until now, in Pegantenan Village, there is no system capable of bridging between the government and Pegantenan Village residents using information technology. Village government services still apply the conventional system, which requires residents to come to the village office and takes a long time. Residents also have difficulty receiving information and submitting reports related to village conditions. In this service, a mobile-based village service application was developed so that it can be accessed by all residents in order to realize the Smart Village program and efforts towards implementing a transparent and progressive Village Government. The method of implementing activities consists of the data collection stage such as business processes and forms that residents use when handling letters. The next stage is making mobile-based applications and application socialization as well as sharing sessions about experiences while using the application. The result of this service is a mobile-based service application system for Pegantenan Village. There is also a web application that is used as an administrator. The mobile application is intended for residents while the web application is intended for admins, namely village officials. Mobile and web-based application systems allow residents to access the system anywhere and anytime so as to improve the quality of village government services to residents.
\end{abstract}

Keywords: village service application; mobile application; smart village; pegantenan village. 


\section{PENDAHULUAN}

Perkembangan teknologi informasi merupakan hal yang tidak bisa dihindari, terlebih pada saat ini penguasaan teknologi informasi dijadikan sebagai salah satu indikator kemajuan suatu negara. Dalam konteks Indonesia, perkembangan teknologi informasi terjadi hampir di seluruh aspek, mulai dari penyelenggaraan pemerintahan sampai dengan kehidupan masyarakat (Andari, Irawan, \& Latuconsina, 2017).

Perkembangan teknologi informasi dalam konteks pemerintahan dimulai sejak diberlakukannya Instruksi Presiden Nomor 3 Tahun 2003 yang menjadi pintu gerbang penerapan electronic government dan menjadi manifestasi akan komitmen pemerintah dalam penyelenggaraan pemerintahan dengan berbasis kepada pemanfaatan infrastruktur teknologi informasi (Wati \& Despahari, 2018). Pemanfaatan teknologi informasi dalam penyelenggaraan pemerintahan banyak mengalami perkembangan. Teknologi informasi tidak hanya digunakan dalam penyelenggaraan administrasi pemerintahan, tetapi juga dalam memberikan pelayanan publik kepada masyarakat berbasis elektronik yang diterapkan mulai dari pemerintah pusat sampai dengan pemerintah desa (Soegiarto, Kirana, \& Bahar, 2018).

Menurut UU No. 5 Tahun 1979 yang menjelaskan bahwa desa adalah suatu wilayah yang ditempati oleh sejumlah penduduk sebagai kesatuan masyarakat, termasuk di dalamnya kesatuan masyarakat dan hukum yang mempunyai organisasi pemerintahan terendah langsung di bawah camat dan berhak menyelenggarakan rumah tangganya sendiri dalam ikatan Negara Kesatuan Republik Indonesia. Desa sebagai unit pemerintahan terendah dalam struktur pemerintahan Indonesia juga memerlukan pembaharuan dan adopsi terhadap perkembangan teknologi informasi (Said \& Prasetyo E.P., 2019). Dalam proses pembangunan desa, pemanfaatan teknologi informasi menjadi penting dan menjadi bagian dalam mendorong keberhasilan pembangunan desa. Pemanfaatan teknologi informasi harus mampu meciptakan hubungan yang lebih kuat antara pemerintah desa dengan masyarakat. Teknologi informasi dijadikan sebagai media untuk menghubungkan keduanya (Usmanto, Immawan, Fauzi, Sari, \& Mahdi, 2018).

Desa Pegantenan adalah sebuah desa yang terletak di Kecamatan Pegantenan Kabupaten Pamekasan Dengan luas wilayah kurang lebih $258.1765 \mathrm{Ha}$ dan mempunyai jumlah penduduk 3.492 jiwa (Anonymous, 2018). Desa yang merupakan salah satu desa percontohan di Kabupaten Pamekasan ini dikenal dengan sejumlah prestasinya, baik di tingkat Kabupaten hingga Provinsi, salah satunya yakni pada tahun 2018 Desa Pegantenan meraih peringkat ke-3 dalam Perangkingan Desa Terbaik dan Pendampingan P3MD Terbaik dalam Pembangunan dan Pemberdayaan Masyarakat Desa Provinsi Jawa Timur. Foto Kepala Desa Pegantenan dan Penghargaan yang telah diraih bisa dilihat pada Gambar 1. Desa Pegantenan memiliki banyak potensi yang seharusnya bisa dikelola dan dikembangkan dengan maksimal sehingga dapat memberikan manfaat yang lebih bagi masyarakat.

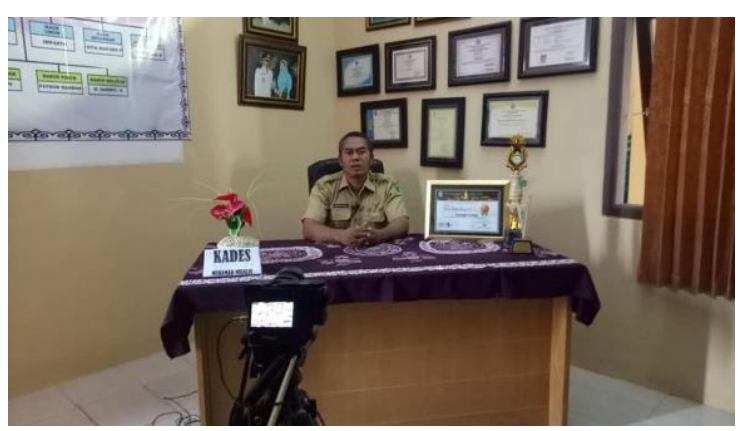

Gambar 1. Foto Kepala Desa dan

Penghargaan yang Diraih oleh Desa Pegantenan

Mengingat Desa Pegantenan yang masih dalam proses berkembang dalam menyampaikan informasi masih dilakukan secara manual dan potensi desa yang kurang terpublikasi, dengan itu masyarakat desa Pegantenan masih kesulitan dalam menerima informasi dari pemerintah desa maupun menyampaikan berbagai saran dan aspirasi masyarakat. Berdasarkan permasalahan tersebut kami merancang sebuah aplikasi pelayanan desa berbasis mobile yang dapat diakses oleh seluruh masyarakat Desa Pegantenan dapat mewujudkan program Smart Village (Herdiana, 2019) dan upaya menuju Penyelenggaraan Pemerintah Desa yang transparan dan berkemajuan.

Tujuan dari kegiatan pengabdian ini adalah untuk meningkatkan pelayanan Desa Pegantenan dalam memberikan pelayanan kepada warga dalam pembuataan surat-surat. Selain itu warga juga bisa menerima pengumuman penting dari desa melalui aplikasi tersebut. Begitu juga warga bisa menyampaikan aspirasi dan info kejadian di Desa Pegantenan malalui aplikasi tersebut. Dengan adanya aplikasi ini diharapkan Pemerintah Desa dapat berkomunikasi dan berinteraksi langsung dengan masyarakat secara update, akurat dan efisien sehingga memudahkan masyarakat Desa Pegantenan 
dalam mengakses informasi publik dan fasilitas umum lain yang telah disediakan.

\section{METODE}

Mitra dalam pengabdian ini adalah warga dan perangkat Desa Pegantenan Kecamatan Pegantenan Kabupaten Pamekasan dengan target ketika sosialisasi ada 30 peserta yang hadir. Metode pelaksanaan kegiatan penerapan aplikasi pelayanan desa berbasis mobile dengan konsep smart village di Desa Pegantenan terdiri dari tahap pengumpulan data, tahap pembuatan aplikasi, dan tahap penerapan aplikasi di Desa Pegantenan.

\section{Tahap Pengumpulan Data}

Tahap ini bertujuan untuk memperoleh data-data desa yang akan digunakan sebagai masukan dari sistem. Dengan melakukan survei langsung dan wawancara kepada pihak terkait yang bertujuan untuk menentukan requirement user dan mengumpulkan data seperti data kependudukan, data informasi APB Desa, data surat-menyurat dan data-data lainnya (Jaja, Herry, \& Afandi, 2014). Data yang digunakan adalah data ril serta akurat yang diperoleh dari pegawai balai Desa Pegantenan.

\section{Tahap Pembuatan Aplikasi}

Dari data dan requirement yang didapatkan, selanjutnya dilakukan analisa dan perencanaan terhadap sistem yang akan dibuat dalam proyek ini. Yang meliputi design sistem, perancangan database, analisa data dan perancangan user interface. Dari hasil mockup user interface yang sudah dibuat selanjutnya dilakukan pengujian tampilan awal kepada mitra, apakah desain yang digunakan sudah memiliki User Interface dan User Experience yang baik bagi mitra sasaran. Langkah Selanjutnya adalah membuat database, database berfungsi sebagai tempat penyimpanan data-data yang telah diberikan oleh petugas balai desa.

Sistem yang telah dirancang selanjutnya diimplementasikan menjadi kode yang akan dibuat menjadi aplikasi web dan mobile. Admin adalah petugas desa yang bertugas menyimpan dan mengelola data Desa seperti data kependudukan, laporan APB desa, surat-surat desa dan menampung aspirasi masyarakat desa (Fitri, Nasution, \& Herwin, 2015). Admin menggunakan aplikasi berbasis web yang dibuat menggunakan framework Laravel. Sedangkan user menggunakan aplikasi berbasis mobile yang dibuat menggunakan framework Flutter. Dimana user dapat melihat informasi-informasi seputar desa. Selain menerima informasi user juga dapat mengirim laporan, memberi saran dan aspirasi, serta dapat melakukan surat-menyurat tanpa harus datang ke balai desa.

\section{Tahap Penerapan Aplikasi di Desa Pegantenan}

Langkah berikutnya adalah dengan melakukan penerapan aplikasi kepada masyarakat dan petugas balai desa Pegantenan. Pada penerapan aplikasi ini diharapkan dapat menciptakan hubungan yang lebih kuat antara pemerintah desa dan masyarakat desa Pegantenan.

Bentuk sosialisasi yang akan dilakukan adalah dengan melakukan sosialisasi melalui kumpul musyawarah desa yang biasanya dilakukan setiap 1 tahun sekali, yang meliputi pembagian sebuah brosur berukuran A4 yang berisi cara penggunaan aplikasi dan keunggulan-keunggulan dari aplikasi pelayanan desa berbasis mobile ini. Bentuk pelatihan yang akan dilakukan kepada petugas balai desa dan masyarakat desa pegantenan dalam hal ini yaitu perihal penggunaan aplikasi mobile dan web.

\section{HASIL DAN PEMBAHASAN Pembuatan Aplikasi}

Sistem yang dibangun terdiri dari 2 aplikasi yaitu aplikasi mobile dan web admin. Admin adalah petugas desa yang bertugas menyimpan dan mengelola data desa. Sedangkan yang mobile akan digunakan oleh warga Desa Pegantenan. Secara umum gambaran sistem yang akan dibuat ditunjukkan pada Gambar 2.

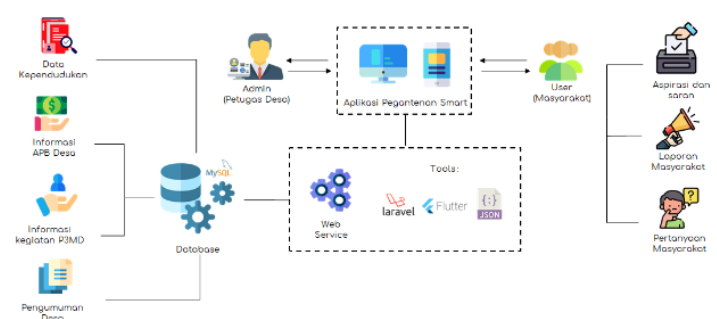

Gambar 2. Desain Sistem Aplikasi

Berdasarkan Gambar 2 diatas, dapat diketahui bahwa bagaimana proses penyajian informasi dan layanan pemerintahan desa dari petugas desa ke masyarakat desa. Adapun penjelasan dari desain sistem sebagai berikut:

\section{Admin}

Admin adalah petugas desa yang bertugas menyimpan dan mengelola data-data desa seperti data kependudukan, laporan APB desa, surat-menyurat dan menyampaikan informasi-informasi desa. Selain itu admin juga bertugas untuk melayani masyarakat desa 
seperti menjawab pertanyaan-pertanyaan masyarakat, menampung saran dan aspirasi masyarakat, serta menerima dan menindaklanjuti laporan dari masyarakat Kemudian data-data tersebut disimpan pada server website admin.

\section{Web Service}

Pada pengabdian kepada masyarakat ini, penulis membangun web service yang dapat saling melayani request satu sama lain maupun melayani request dari aplikasi mobile. Web service tersebut dibangun dengan menggunakan framework Laravel.

Setelah desain dari sistem sudah dibuat kemudian merancang desain tampilan atau mockup. Mockup merupakan sebuat visualisasi sebuah konsep desain, sebagai gambaran nyata rancangan produk, atau preview sebuah ide yang terlihat seperti wujud aslinya. Gambar 3 merupakan mockup aplikasi mobile Pegantenan Smart Village yang didesain menggunakan Aplikasi Adobe XD.
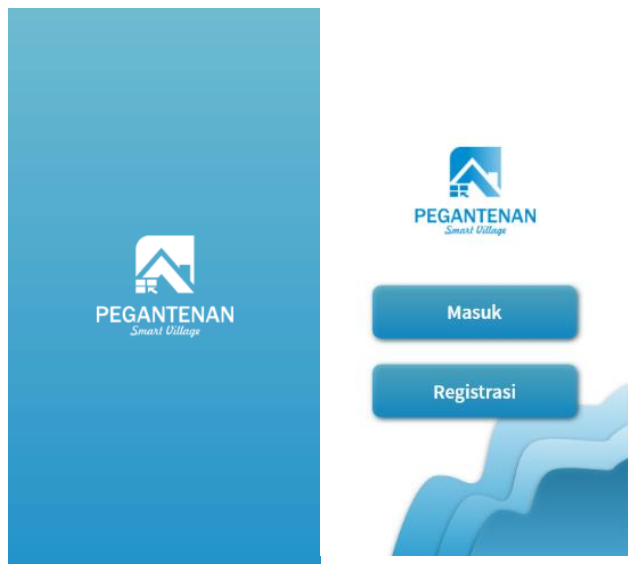

Gambar 3. Mockup Aplikasi Mobile User

Setelah melakukan tahap perancangan sistem dan mockup kemudian masuk pada tahapan pembuatan sistem. Web admin dan web service dibangun menggunakan frameweork Laravel, aplikasi mobile dibangun menggunakan framework Flutter dan MySQL digunakan sebagai penyimpanan data. Web admin dibangun menggunakan framework Laravel, untuk mengkoneksikannya dengan MySQL dapat dilakukan konfigurasi pada file .env dengan cara menambahkan nama database, username dan juga password.

Selanjutnya yakni membuat halaman login, dimana login merupakan proses yang paling penting pada sebuah website agar tidak semua orang dapat mengakses wesite dengan bebas. Sehinga, untuk dapat mengakses fiturfitur admin harus melakukan login terlebih dahulu dengan menginputkan email dan password yang sudah terdaftar pada database.
Setelah melukan login admin langsung masuk pada halaman beranda dimana pada halaman ini terdapat icon dan menu-menu untuk setiap fitur-fiturnya. Pada navbar terdapat nama administrator, notifikasi dan juga logout seperti pada Gambar 4.

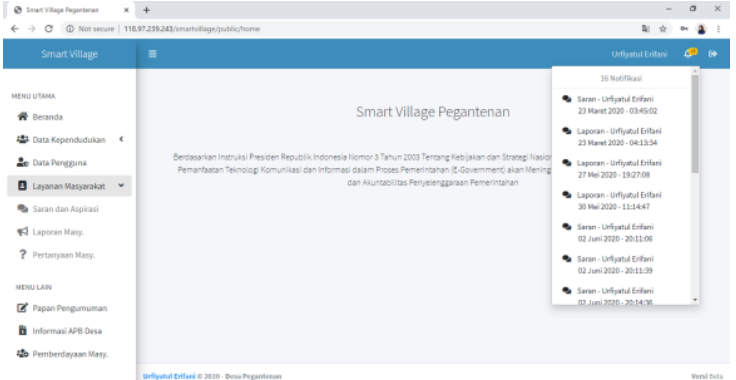

Gambar 4. Halaman Beranda Web Admin

Aplikasi mobile dibangun menggunakan framework Flutter. Pada Gambar 5 merupakan stuktur class yang diimplementasikan pada pembuatan aplikasi mobile.

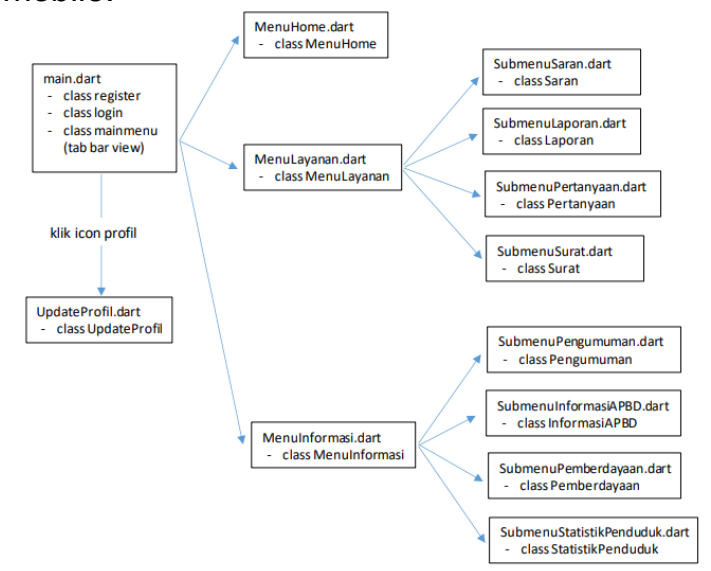

Gambar 5 Struktur class pada flutter

Dari Gambar 5 terdapat 12 tampilan yang ada di aplikasi mobile. Empat tampilan utama yang mana dua tampilan mempunyai 4 sub-tampilan. Sub-tampilan tersebut mempunyai fungsi yang ditujukan untuk pengguna/warga untuk menyampaikan saran, laporan, pertanyaan, melihat pengumuman, APBD, pemberdayaan, dan statistik penduduk. Beberapa tampilan aplikasi mobile bisa dilihat pada Gambar 6.

Tampilan pada Gambar 6 merupakan tampilan halaman register dan halaman profile. Setelah pengguna membuka aplikasi untuk pertama kalinya akan diarahkan untuk login atau register. Register digunakan bagi pengguna yang belum mempunyai akun sehingga perlu mendaftarkan data dirinya berupa NIK, nama, nomor telepon, username, dan password. Apabila pengguna sudah pernah daftar kemudian handphone nya ke-reset 
sehingga aplikasinya hilang tinggal mengunduh aplikasi dan login menggunakan username dan password yang sudah dimilikinya.

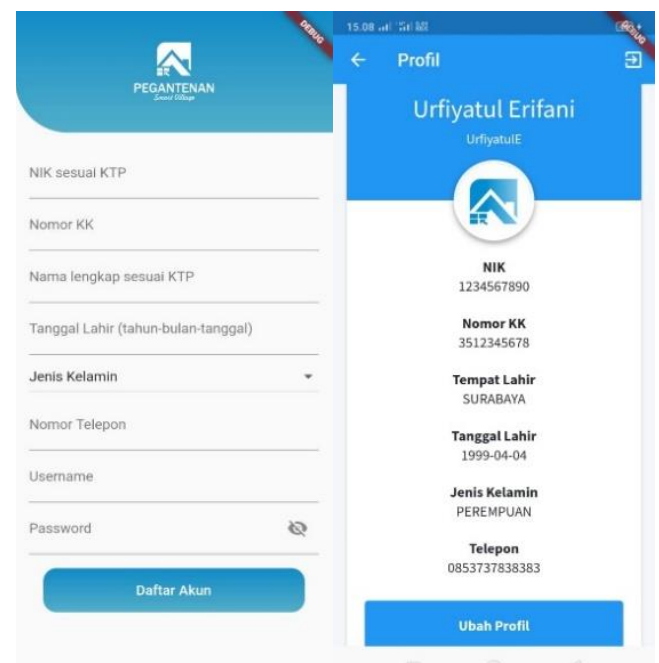

Gambar 6. Tampilan Aplikasi Mobile (a) Halaman Register (b) Halaman Profile

Tampilan yang tidak kalah penting berikutnya adalah menu layanan dan informasi. Menu Layanan berisi 4 sub menu yaitu Aspirasi dan Saran, Laporan, Pertanyaan, dan Surat Menyurat. Sedangkan sub menu dari menu Informasi adalah Pengumuman, Informasi APBD, Pemberdayaan Masyarakat, dan Statistik Penduduk. Tampilan sub menu dari menu Layanan dan Informasi dapat dilihat pada Gambar 7.

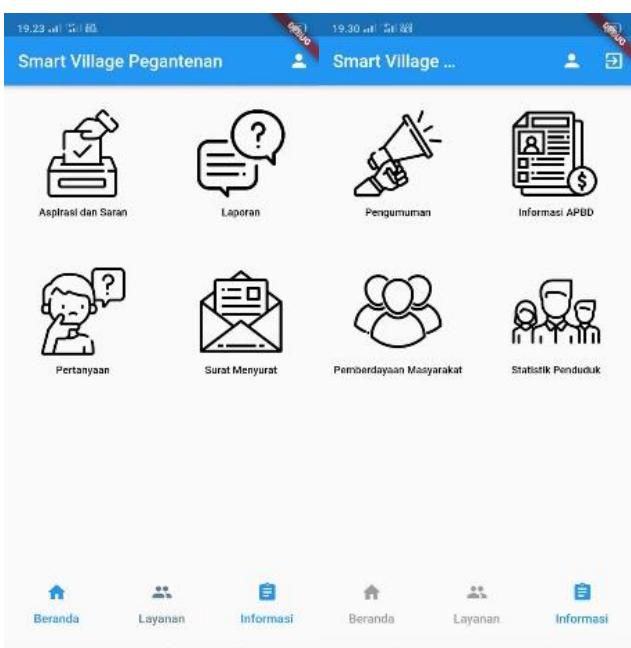

Gambar 7. Tampilan Aplikasi Mobile (a) Menu Layanan (b) Menu Informasi

Pada Menu layanan terjadi komunikasi antar user dan admin. Pada uji coba fitur ini mencoba apakah setiap icon berhasil menampilkan fitur-fiturnya. Pada pengujian Aspirasi dan saran user terlebih dahulu memilih opsi saran dan aspirasi apakah tentang Pengembangan Desa, Pembangunan Infrastuktur, Pemberdayaan Masyarakat apabila diluar opsi tersebut user dapat memilih opsi lain-lain. Setelah itu user dapat memberikan keteragan saran dan aspirasi serta dapat menambahkan foto atau dokumentasi. Data saran dan aspirasi akan masuk pada tabel data saran di aplikasi website admin. Selain menampung saran dan aspirasi Admin juga dapat merubah status saran yang apakah saran tersebut diterima, dalam proses atau selesai. Sehingga masyarakat mengetahui saran tersebut telah mendapat tanggapan dari perangkat desa.

\section{Sosialisasi dan Pelatihan}

Sosialisasi dan pelatihan dilaksanakan pada tanggal 5 September 2020 ditempat Balai Desa Pegantenan. Pada kegiatan sosialisasi dan pelatihan dihadiri oleh kepala desa, perangkat desa, dan masyarakat. Acara kegiatan sosialisasi dan pelatihan berjalan lancar dengan susunan acara seperti pada Tabel 1.

Ketika sesi penyuluhan yang diisi oleh pemateri dari Dosen PSDKU PENS Sumenep dengan topi seputar pentingnya e-goverment di linkungan pemerintahan. Kemudian dilanjut dengan acara sosialisasi aplikasi Pegantenan Smart village kepada masyarakat dan perangkat Desa Pegantenan. Dari sosialisasi tersebut didapatkan antusias warga yang begitu besar terhadap aplikasi Pegantenan Smart village karena pada aplikasi tersebut terdapat kemudahan dalam mengurus surat-surat yang diperlukan warga.

Selain digunakan untuk mengurus surat-surat secara online, warga juga bisa melaporkan kejadian-kejadian khusus misalkan ada yang kehilangan sepeda motor atau yang lainnya. Warga juga bisa menyampaikan aspirasinya di aplikasi tersebut sehingga admin desa dan dusun bisa melihat apa yang menjadi aspirasi masyarakat dan kejadian-kejadian terkini yang terjadi di sekitar warga. Dokumentasi kegiatan sosialisasi aplikasi Pegantenan Smart village bisa dilihat pada Gambar 8. 
Tabel 1. Susunan Acara Sosialisasi dan Pelatihan Kegiatan Pengabdian Kepada Masyarakat

\begin{tabular}{|c|c|c|}
\hline $\begin{array}{c}\text { Wakt } \\
\text { u }\end{array}$ & Kegiatan & Keterangan \\
\hline $\begin{array}{l}07.00 \\
\overline{0} \\
08.00\end{array}$ & $\begin{array}{l}\text { Berangkat menuju } \\
\text { lokasi }\end{array}$ & $\begin{array}{l}\text { Tim } \\
\text { Pengabdian }\end{array}$ \\
\hline $\begin{array}{l}08.00 \\
- \\
09.00\end{array}$ & $\begin{array}{l}\text { Persiapan } \\
\text { perlengkapan }\end{array}$ & Mahasiswa \\
\hline $\begin{array}{l}09.00 \\
- \\
09.10\end{array}$ & $\begin{array}{l}\text { Pembukaan } \\
\text { kegiatan pengabdian } \\
\text { masyarakat }\end{array}$ & $\mathrm{MC}$ \\
\hline $\begin{array}{l}09.10 \\
- \\
09.20\end{array}$ & $\begin{array}{l}\text { Sambutan Kepala } \\
\text { Desa Pegantenan }\end{array}$ & KaDes \\
\hline $\begin{array}{l}09.00 \\
- \\
09.30\end{array}$ & $\begin{array}{l}\text { Sambutan ketua tim } \\
\text { pengabdian } \\
\text { masyarakat }\end{array}$ & $\begin{array}{l}\text { Ketua Tim } \\
\text { Pengabdian }\end{array}$ \\
\hline $\begin{array}{l}09.30 \\
- \\
10.00\end{array}$ & $\begin{array}{l}\text { Penyuluhan kepada } \\
\text { masyarakat seputar } \\
\text { e-government }\end{array}$ & Pemateri \\
\hline $\begin{array}{l}10.00 \\
- \\
11.30\end{array}$ & $\begin{array}{l}\text { Sosialisasi Aplikasi } \\
\text { Pegantenan } \\
\text { Smartvillage kepada } \\
\text { masyarakat dan } \\
\text { perangkat desa } \\
\text { Pegantenan }\end{array}$ & $\begin{array}{l}\text { Tim } \\
\text { Pengabdian }\end{array}$ \\
\hline $\begin{array}{l}11.00 \\
- \\
11.30\end{array}$ & $\begin{array}{l}\text { Sharring session } \\
\text { dengan masyarakat } \\
\text { masyarakat dan } \\
\text { perangkat desa } \\
\text { Pegantenan }\end{array}$ & $\begin{array}{l}\text { Panitia, } \\
\text { Perangkat } \\
\text { desa dan } \\
\text { Masyarakat } \\
\text { desa }\end{array}$ \\
\hline $\begin{array}{l}12.00 \\
- \\
13.00\end{array}$ & $\begin{array}{l}\text { Istirahat, Sholat, } \\
\text { Makan }\end{array}$ & \\
\hline $\begin{array}{l}13.00 \\
-13.20\end{array}$ & $\begin{array}{l}\text { Pengisian kuisioner } \\
\text { oleh masyarakat dan } \\
\text { perangkat desa } \\
\text { mengenai aplikasi }\end{array}$ & $\begin{array}{l}\text { Perangkat } \\
\text { desa dan } \\
\text { Masyarakat } \\
\text { desa } \\
\end{array}$ \\
\hline $\begin{array}{l}13.20 \\
-13.30\end{array}$ & $\begin{array}{l}\text { Pemberian } \\
\text { cinderamata/kenang } \\
\text {-kenang kepada } \\
\text { pihak desa }\end{array}$ & $\begin{array}{l}\text { Tim } \\
\text { Pengabdian } \\
\text { dan } \\
\text { Perangkat } \\
\text { desa } \\
\end{array}$ \\
\hline $\begin{array}{l}13.30 \\
- \\
13.40 \\
\end{array}$ & $\begin{array}{l}\text { Penutupan kegiatan } \\
\text { pengabdian } \\
\text { masyarakat }\end{array}$ & MC \\
\hline $\begin{array}{l}13.40 \\
-14.00\end{array}$ & Sesi Foto bersama & $\begin{array}{l}\text { Tim } \\
\text { Pengabdian } \\
\text {, Perangkat } \\
\text { desa dan } \\
\text { Masyarakat } \\
\text { desa }\end{array}$ \\
\hline
\end{tabular}

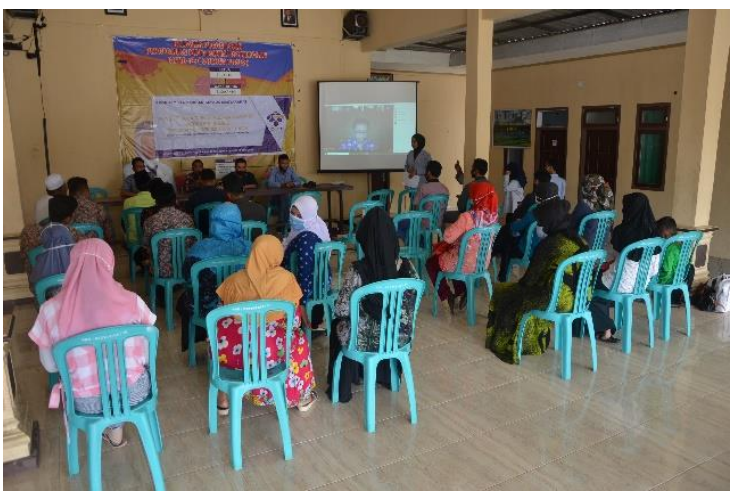

(a)

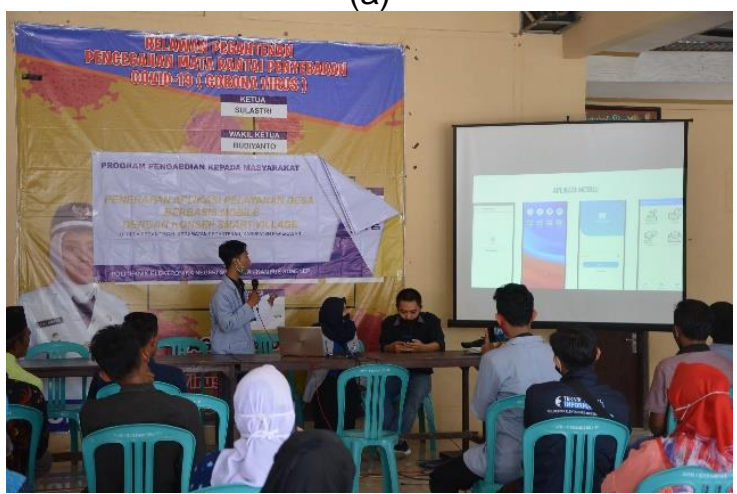

(b)

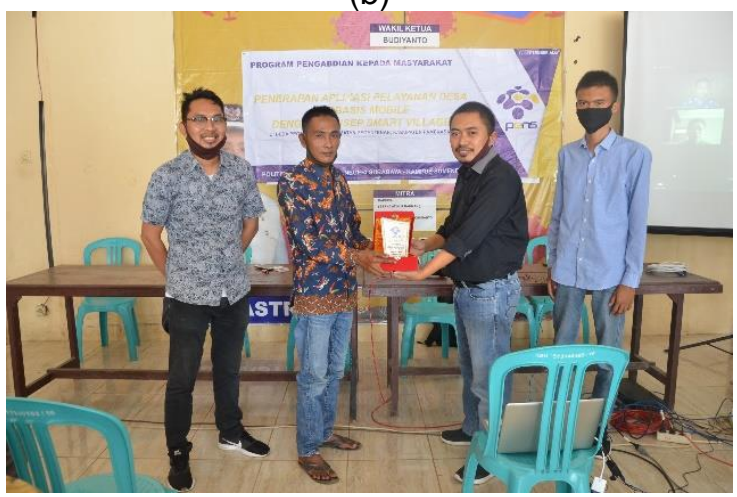

(c)

Gambar 8. Foto Kegiatan Sosialisasi (a) Penyuluhan seputar e-government (b) Sosialisasi Aplikasi Pegantenan Smart village

(c) Pemberian cinderamata

Acara berikutnya adalah sharing session antara tim pengabdian dengan masyarakat dan perangkat desa. Acara ini digunakan untuk mengumpulkan informasi tentang pengalaman warga dan perangkat desa setelah mencoba aplikasi Pegantenan Smart village. Dari hasil sharing session yang telah dilaksanakan hampir tidak ada kendala yang terjadi ketika masyarakat mencoba aplikasi tersebut. Hanya sedikit yang mengalami gagal register atau login karena kesalahan input NIK atau password.

Pada saat akhir sesi acara sosialisasi dan pelatihan ini, dibagikan kuesioner secara 
offline dan online. Yang online untuk perangkat desa dan admin dusun. Sedangkan yang offline untuk warga atau pengguna yang ikut mencoba aplikasi Pegantenan Smart village. Selain itu juga para perangkat desa, admin dusun, dan masyarakat bisa mengisi kuisioner mengenai kesan dan pesan mengenai sosialisasi yang telah dilakukan. Sebelum penutupan diberikan cindera mata dari tim pengabdian masyarakat kepada pihak Desa Pegantenan sebagai kenang-kenangan.

\section{SIMPULAN DAN SARAN}

Dengan adanya aplikasi website Pegantenan Smart Village memudahkan administrator desa dalam mengelola dan menyimpan data-data desa. Aplikasi ini dapat dimanfaatkan oleh pemerintah desa sebagai media untuk menyampaikan berbagai layanan desa dan informasi kepada masyarakat. Memudahkan perangkat desa dalam menyelesaikan permasalahan-permasalahan desa dengan adanya laporan dari masyarakat serta saran dan aspirasi dari masyarakat sehingga keadaan desa menjadi lebih baik. Berbagai macam saran dan aspirasi, laporan terkait keadaan desa, serta pertanyaan masyarakat dapat disampaikan langsung oleh masyarakat desa melalui aplikasi tanpa harus datang ke balai desa. Selain itu masyarakat juga dapat melihat pengumuman yang disampaikan oleh administrator desa.

Aplikasi bisa dikembangkan lagi dengan menambahkan fitur-fitur yang menghubungkan dengan beberapa instansi desa seperti puskesmas dan kantor polisi. User interface pada aplikasi mobile perlu diperbaiki lagi agar tampilannya lebih mudah dimengerti oleh masyarakat desa. Sosialisasi kepada masyarakat desa megenai cara penggunaan aplikasi perlu diadakan secara berkala tidak hanya sekali waktu acara pengabdian kepada masyarakat.

\section{UCAPAN TERIMAKASIH}

Terima kasih kepada Politeknik Elektronika Negeri Surabaya terutama Pusat Penelitian dan Pengabdian kepada Masyarakat, serta warga dan perangkat Desa Pegantenan Kecamatan Pegantenan Kabupaten Pamekasan yang telah membantu secara morel maupun materiel dalam pelaksanaan pengabdian kepada masyarakat sehingga berjalan lancar.

\section{DAFTAR RUJUKAN}

Andari, D. P. D., Irawan, B., \& Latuconsina, R. (2017). Perancangan Dan Implementasi Sistem Manajemen Basis Data Pada Kantor Desa Untuk Menunjang Desa
Cerdas Berbasis Web. E-Proceeding of Engineering, 4(3), 4147-4153.

Anonymous. (2018). PROFIL KECAMATAN PEGANTENAN. Retrieved October 10, 2020, from http://pegantenan.pamekasankab.go.id/in dex.php/profil/visi-dan-misi/8-beritaartikel/5-profil-kecamatan-pegantenan

Fitri, T. A., Nasution, T., \& Herwin. (2015). Pengembangan Model Pelayanan Kantor Desa terhadap Masyarakat Berbasis Mobile Computing. Jurnal Edukasi Dan Penelitian Informatika (JEPIN), 1(2), 116121.

https://doi.org/10.26418/jp.v1i2.12559

Herdiana, D. (2019). Pengembangan Konsep Smart Village Bagi Desa-Desa di Indonesia (Developing the Smart Village Concept for Indonesian Villages). JURNAL IPTEKKOM: Jurnal IImu Pengetahuan \& Teknologi Informasi, 21(1), $1-16$. https://doi.org/10.33164/iptekkom.21.1.20 19.1-16

Jaja, R., Herry, B., \& Afandi, M. (2014). Buku Pintar Sistrem Administrasi dan Informasi Desa. Jakarta.

Said, B., \& Prasetyo E.P., F. (2019). Layanan eSurat Berbasis Mobile Application di Desa Waru Barat Pamekasan. InfoTekJar (Jurnal Nasional Informatika Dan Teknologi Jaringan), 4(1), 111-115. https://doi.org/10.30743/infotekjar.v4i1.16 37

Soegiarto, Kirana, E. C., \& Bahar. (2018). Sistem informasi pelayanan masyarakat pada kantor kelurahan guntung paikat banjarbaru. Prosiding SNRT (Seminar Nasional Riset Terapan), (November), 24-34. Banjarmasin.

Usmanto, B., Immawan, R., Fauzi, Sari, K. P., \& Mahdi, M. I. (2018). Implementasi Web Mobile Sebagai Media Informasi Pemberdayaan Masyarakat $\mathrm{Di}$ Desa Pirngadi. Jurnal Keteknikan Dan Sains, 1(1), 32-40. Retrieved from http://journal.unhas.ac.id/index.php/juteks /article/view/4296

Wati, M., \& Despahari, E. (2018). Sistem Informasi Pelayanan Administrasi Kependudukan dan Catatan Sipil Kelurahan Di Kecamatan Marangkayu Kutai Kartanegara. Jurti (Jurnal Rekayasa Teknologi Informasi), 2(1), 47-54. 